УДК 781.62.071.1(430)

DOI 10.34064/khnum2-1609

\title{
Олена Станішевська
}

ORCID 0000-0002-7447-1580

Харківский національний університет мистецтв імені І. П. Котляревського, майдан Конституизї 11/13, Харків, 61003, Україна hellenass1992@gmail.com

\section{ВЗАЄМОДІЯ ПОЕТИЧНОГО ТЕКСТУ ТА МУЗИКИ В ОПУСІ 49 Й. БРАМСА}

\section{АНОТАЦІЯ}

Станішевська Олена. Взаємодія поетичного тексту та музики в опуci 49 Й. Брамса.

У статті розглядається опус 49 Й. Брамса (який не дістав пильної уваги з боку науковців) в аспекті взаємодії поетичного тексту і музики. Виявляються особливості трактування і відтворення поетичного тексту композитором, який одночасно тяжіє до узагальненості і деталізації, наслідуючи традицію Ф. Шуберта і Р. Шумана. Зазначається, що у передачі смислу обраних поезій Й. Брамс використовує прийом ключових слів. Досліджуються прийоми внутрішньої циклізації в організації цілого. 3'ясовується характер взаємодії вокальної та фортепіанної партій, яка мислиться як інструментальне узагальнення. Акцентується увага на інтонаційних складнощах німецької мови, які полягають у великій кількості приголосних. Кожний номер опусу розглядається з точки зору подолання інтонаційних складнощів композитором і можливих шляхів їх подолання виконавцями. В аспекті взаємодії словесного та музичного інтонування розкривається специфіка обраного опусу.

Ключові слова: опус; інтонація; пісня; цикл; мелодія; Й. Брамс. 


\section{АННОТАЦИЯ}

Станишевская Елена. Взаимодействие поэтического текста и музыки в опусе 49 Й. Брамса.

В статье рассматривается опус 49 Й. Брамса (который обойден вниманием исследователей) в аспекте взаимодействия поэтического слова и музыки. Выявляются особенности трактовки и претворения поэтического текста композитором, который одновременно тяготеет к обобщению и детализации, наследуя традицию Ф. Шуберта и Р. Шумана. Отмечается, что в передаче смысла избранных стихотворений Й. Брамс использует прием ключевых слов. Исследуются приемы внутренней циклизации в организации целого. Выясняется характер взаимодействия вокальной и фортепианной партий, которая мыслится как инструментальное обобщение. Акцентируется внимание на интонационных трудностях немецкого языка, которые состоят в большом количестве согласных. Каждый номер опуса рассматривается с точки зрения преодоления интонационных трудностей композитором и возможных путей выхода их них исполнителями. В аспекте взаимодействия словесного и музыкального интонирования раскрывается специфика избранного опуса.

Ключевые слова: опус; интонация; песня; цикл; мелодия; Й. Брамс.

\section{ABSTRACT}

\section{Stanishevska Olena. The Interaction of Poetic Text and Music in Opus 49 by J. Brahms}

Introduction. In scientific literature dedicated to J. Brahms, much attention has been paid to a song genre. The researches note that J. Brahms's songs can be regarded as a continuation of genre-specific features of Austro-German Lied, which retains the purity of the generic semantics in the composer's works, without involving typically operatic means of vocal intoning, or approaching the so-called "poem with music".

J. Brahms's songs do not allow the singer to demonstrate the full range of his/her voice, to reveal his/her artistic temperament, to show the technical skill. Absorption in a special emotional aura of J. Brahms's songs requires a variety of timbre-intonational resources of a singer, his/her ability not to lose the sense of the whole while detailing the melodious overture. Of particular interest is the issue of music and words correlation in J. Brahms's songs. As a rule, the composer is considered to be the immediate successor of F. Schubert rather than R. Schuman 
in his orientation to musical embodiment of a generalized poetic image. At the same time, this issue requires more detailed study, since the composer was very sensitive to the poetic text, in particular, from the point of view of coordinating the intonation-phonetic features of German language and vocal intonation.

Theoretical Background. Recent research and publications analysis. Opus 49 by J. Brahms seems to be in the shadow of musicological thought and performing practice. It should be noted that a very famous opus part is "Lullaby", which is mentioned in the monographs of K. Tsareva (1986), M. Druskin (1959), and K. Geiringer (1965). In the literature being considered the abovementioned opus is not completely covered, thus determining the relevance of our article. There are references to individual songs in different sources, but incidentally, in the context of different issues.

Objective is to study J. Brahms's opus 49 in the aspect of the interaction of poetic word and music, verbal and musical intoning.

Methods: 1) historical method, allowing to comprehend the selected material in the perspective of the development of Austro-German song of the XIX century; 2) intonational method, which involves the study of vocal melody in terms of phonetic-tonic links; 3) genre method, caused by the features of chamber vocal lyrics; 4) stylistic method, corresponding to a specific opus consideration in the general context of the composer's creative work.

Results and Discussion. The composer did not have any tendency to the songs cyclization, however, the vocal miniatures, assembled in one opus, appear to be lyrical notes, self-contained but united by poetic motives and nature of the author's expression. Many researchers see a cyclic organization of his particular vocal opuses. For example, I. Mykhailov (1987: 19) proves the existence of cyclic principles at different compositional levels in composer's songs: separate "melodious pairs", a number of songs with the texts by one poet inside the opus, a whole vocal opus with the texts by different authors. According to I. Mikhailov, the cyclic connection of songs is emphasized by several compositional techniques: thematic one, i.e. the unity of the musical material; the continuity of songs alternation, which is sometimes manifested in the absence of a piano introduction of the next song.

In opus 49, the author chooses different poetic sources - poems by P. Heyse, L. Hölty, A. F. Schack, and J. Wenzig. The composer refers to one of the samples of the famous collection by Joachim von Arnim and Clemens Brentano "The 
Magic Horn of a Boy". Given the anthological principle of poetic texts selection, no transparent storyline in opus 49, such as "A Beautiful Miller" by F. Schubert or "Poet's Love" by R. Schumann, there is no reason to regard it as a cycle. However, the opus' songs are arranged in a certain semantic sequence. Owing to the fact that three songs ("Sunday Morning", "To a Violet", "Longing for the Sweetheart") are united by homogeneous poetic motifs, one can regard them as forming a microcycle within the whole. The second micro-cycle of the opus is represented by No. 4 and No. 5 ("Lullaby" and "Twilight").

In interpreting the poetic text, J. Brahms adheres to the principle of emotional and musical generality, once detailing the text, if at all. Here, he succeeds F. Schubert.

However, he uses the technique of keywords, distinguishing them in two ways: rhythmically (with syncope) and through intrinsic chants; the composer also uses different types of intoning.

Following the tradition of the $19^{\text {th }}$-century Austro-German song, the composer regards the genre as an alliance of two full members: the vocalist and the pianist, with the part being an instrumental generalization.

The intonational image of the whole in vocal music arises at the crossing of two texts - poetic and musical. German has intonation difficulties owing to a large number of consonants. Problems, encountered by the singers in intoning German language, are compensated by the consonants and vowels, which are most favorable for correct sound formation, allowing to achieve the required quality. The soft consonants and vowels should be regarded as the ideal vocal sound, that is, a model for other phonemes in musical-poetic text. While creating vocal melodies of Opus 49 songs, J. Brahms cares the phonetics of a German text in the singing to be comfortable for the performer.

Conclusions. J. Brahms uses such principles and techniques of literary original musical embodiment as preservation of the holistic image, created by the author of the poems, on the one hand, and its detailing on the other. In the second case, the composer resorts to all means of musical expression: motive-thematic, texture-register, rhythmic, harmonious, texture ones. The prospects of the research lie in studying the interaction of verbal and musical intonation in other vocal works of J. Brahms, as well as in chamber-vocal music of late romantics.

Key words: opus; intonation; song; cycle; melody; J. Brahms. 
Постановка проблеми. У дослідницькій літературі міститься різноманітний аналітичний матеріал, що розкриває духовний, образно-емоційний і музичний світ Й. Брамса. Значну увагу приділено пісенному жанру в творчості композитора, до якого зверталися музикознавці різних поколінь, у тому числі Н. Васіна-Гроссман (1966), М. Друскін (1959), І. Михайлов (1987), К. Царьова (1986). В їх працях пісні Й. Брамса постають продовженням жанрових особливостей австро-німецької Lied, що зберігає в творах композитора чистоту родової семантики поза залучення типово оперних засобів вокального інтонування або зближення з так званим «віршем з музикою». Брамсівська лірика сувора і благородна та разом 3 тим відкрита до довірливого спілкування. У кожному опусі пісень названі властивості камерно-вокальних мініатюр композитора розкриваються в усьому різнобарв'ї емоційних переживань, які ніколи не переходять за межу інтимного висловлювання. У цьому плані пісні Й. Брамса представляють певні труднощі для вокально-виконавського висловлювання. Вони не дають можливості співакові продемонструвати весь діапазон свого голосу, розкрити артистичний темперамент, блиснути технічною майстерністю. Одночасно заглибленість в особливу емоційну ауру пісень Й. Брамса вимагає різноманіття темброво-інтонаційних ресурсів співака, його вміння при деталізації мелодійного начала не втратити відчуття цілого. Особливого інтересу заслуговує питання про співвідношення в піснях Й. Брамса музики і слова. Як правило, композитора вважають безпосереднім спадкоємцем швидше Ф. Шуберта, ніж Р. Шумана в його орієнтації на музичне втілення узагальненого поетичного образу. Разом з тим, це питання потребує більш докладного вивчення, оскільки, як показує аналіз пісень Й. Брамса, композитор дуже чуйно ставився до поетичного тексту, зокрема, з точки зору координації інтонаційно-фонетичних особливостей німецької мови та вокальної інтонації.

Аналіз літератури. Опус 49 Й. Брамса знаходиться немовби в тіні музикознавської думки і виконавської практики, через те, що i виконавців, і науковців приваблює більш яскрава музика композито- 
ра. Треба зазначити, що дуже відомим номером опусу є «Колискова», яка згадується в монографіях К. Царьової (1986), М. Друскіна (1959), К. Гейрінгера (1965). У доступній нам літературі названий опус повністю не висвітлюється, що зумовлює актуальність нашої статті. Згадки щодо окремих пісень зустрічаємо в різних джерелах, але мимохідь, в контексті різної проблематики. Відсутність літератури щодо названого опусу тим більше виявляється дивним, що інші твори Й. Брамса досліджуються дуже активно.

Метою цієї статті в контексті вищезазначеного $є$ розгляд опусу 49 Й. Брамса в аспекті взаємодії поетичного слова і музики, словесного та музичного інтонування.

Методи дослідження: 1) історичний, який дозволяє осмислити обраний матеріал в перспективі розвитку австро-німецької пісні XIX століття; 2) інтонаційниц̆, який передбачає вивчення вокальної мелодики з точки зору фонетико-тонічних зв'язків; 3) жанровий, викликаний особливостями камерно-вокальної лірики; 4) стильовий, який відповідає розгляду конкретного опусу в загальностильовому контексті творчості композитора.

Виклад основного матеріалу. Композитор не тяжів до циклізації пісень, однак, зібрані під одним опусом вокальні мініатюри постають свого роду ліричними нотатками, вельми самодостатніми, але пов'язаними поетичними мотивами і характером авторського висловлювання. Цікавим є той факт, що композитор створив лише один вокальний цикл (15 романсів 3 «Магелони» Л. Тіка ор. 33), хоча багато дослідників вбачають циклічну побудову в його певних вокальних опусах. Так, наприклад, I. Михайлов (1987: 19) доводить існування у піснях композитора циклічних принципів на різних композиційних рівнях: окремих «пісенних пар», ряду пісень на тексти одного поета всередині опусу, цілого вокального опусу на тексти різних авторів. Циклічний зв’язок пісень, на думку I. Михайлова, підкреслюється декількома композиційними прийомами: тематичним, тобто єдністю музичного матеріалу; безперервністю чергування пісень, що проявляється іноді у відсутності фортепіанного вступу наступної пісні. На підгрунті зроблених спостережень дослідник робить висновок, про те, що деякі пісенні опуси Й. Брамса, які не мають авторського 
визначення «цикл», фактично є циклами (1987). Вказуючи на принципи об'єднання вокальних мініатюр в опуси і навіть називаючи їх іноді циклами, К. Царьова (1986) вважає, що Й. Брамс, на відміну від Р. Шумана, не схильний до створення вокальних циклів.

В опусі 49 автор обирає різні поетичні джерела - вірші П. Хейзе, Л. Хельті, А. Ф. Шака, Й. Венціга, тобто створені сучасниками Й. Брамса. Належність композитора і поетів єдиному зрізу історичного часу забезпечує співзвучність їх світовідчуття. Крім зазначених літературних оригіналів, композитор звертається до одного зі зразків знаменитого збірника Ахима фон Арніма та Клеменса Брентано «Чарівний ріг хлопчика». 3 огляду на антологічний принцип підбору поетичних текстів, відсутність в опусі 49 наскрізної сюжетної лінії, на зразок «Прекрасної мірошнички» Ф. Шуберта або «Любові поета» Р. Шумана, назвати його циклом немає підстав. Проте пісні опусу розташовуються у певній послідовності: він відкривається піснею сюжетного характеру, в якій спочатку виставлені романтичні знаки обдуреного кохання. Любовна тематика знаходить продовження у піснях № 2 і № 3, в яких виникає типово романтичне почуття туги за втраченим щастям. В силу того, що три пісні («Недільний ранок», «До фіалки», «Туга за милою») об'єднані однорідними поетичними мотивами, можна сказати, що вони утворюють мікроцикл всередині цілого. Нагадаємо, що здійснення циклічних принципів на різних композиційних рівнях I. Михайлов (1987) вважає однією з характерних особливостей брамсівського ліричного висловлювання.

Другий мікроцикл опусу представляють № 4 та № 5 («Колискова» та «Сутінки»). Відштовхуючись від ключових слів, що входять до назви першої та п'ятої мініатюр, правомірно говорити про втілення Й. Брамсом однієї з одиниць життєвого циклу, що також надає простій послідовності пісень властивості цілісної композиції.

У тлумаченні поетичного тексту Й. Брамс дотримується принципу емоційної та музичної узагальненості, лише зрідка деталізуючи текст. У цьому сенсі він виступає наступником Ф. Шуберта. 3 цього приводу В. Васіна-Гроссман (1966) відмічає, що близькість до Ф. Шуберта «відчувається не тільки в значенні мелодійного начала, у зв'язку пісень з народно-побутовими витоками, а й у місці, що займає пісня 
серед інших жанрів. Як і у Шуберта, пісня у Брамса живила собою тематизм інструментальних творів, надаючи йому безпосередню живу виразність» (1966: 234). Таким чином, Й. Брамс спирається на різні індивідуально-творчі традиції австро-німецької пісні XIX століття, що надає його камерно-вокальним мініатюрам об'єктивований характер. Це інтимна музика, позбавлена яскравих спалахів, екстатичних проривів, у чому полягає одна з істотних відмінностей ліричного висловлювання Й. Брамса від сучасної йому пізньоромантичної лірики. 3 іншого боку, композитор в цілому не тяжіє до театралізації пісні - на противагу його молодшому сучасникові Хуго Вольфу.

Продовжуючи традиції Ф. Шуберта, Й. Брамс передає зміст літературного тексту досить узагальнено. Разом з тим, він використовує прийом ключових слів, які композитор виділяє двома засобами: ритмічно (синкопами) і за рахунок внутрішньоскладових розспівів. Композитор застосовує різні типи інтонування - кантиленний, який переважає в більшості пісень і базується на плавності мелодії, широті мелодійного дихання; декламаційний, який приурочений здебільшого до кульмінаційних моментів музичної драматургії, та мовленнєвий, ніде не втрачаючи при цьому цілісності мелодійної лінії.

Цілком наслідуючи традицію австро-німецької пісні XIX століття, композитор мислить жанр як союз двох повноправних учасників: вокаліста та піаніста. Фортепіанна партія представляє собою інструментальне втілення поетичного образу, яким він бачиться Й. Брамсу. Ми маємо справу з подвійним виміром композиторської інтерпретації - вокальним началом, яке інтонаційно втілює поетичний текст, та інструментальним узагальненням, тому ніде не можна говорити про акомпанемент. Фортепіанна партія трактується по-різному: іноді це фон, іноді - мелодійне доведення, часом - подвоєння мелодійного голосу або елементи звукозображання.

Інтонаційний образ цілого у вокальній музиці виникає на перетині двох текстів - поетичного і музичного. Німецька мова має інтонаційні складнощі. Вона ускладнена великою кількістю приголосних, які нібито зупиняють, переривають вокальну лінію, що не прийнятне для єдиного цілісного фразування у співі. Складнощі, що виникають перед співаками в інтонуванні німецької мови, 
компенсуються наявністю в ній приголосних та голосних, найбільш сприятливих для правильного звукоутворення, i дозволяють досягти потрібної іiі якості. Саме від м'яких приголосних і голосних слід відштовхуватися як ідеалу вокального звучання, тобто зразка для інших фонем, що зустрічаються в музично-поетичному тексті. У створенні вокальних мелодій пісень опусу 49 Й. Брамс ретельно стежить за тим, щоб фонетика німецькомовного тексту у співі була зручною для виконавця. Так, у пісні «Недільний ранок» композитор досить комфортно для вокаліста співвідносить текстовий матеріал 3 музичним: на усі сильні долі в тактах припадає склад зі зручними голосними, такими як $\boldsymbol{a}, \boldsymbol{o}, \boldsymbol{e}, \boldsymbol{i}$, і подібний принцип зберігається протягом усієї пісні. Композитор враховує усі вокальні нюанси та намагається зробити твір найбільш сприятливим для виконання. Головне завдання співака - дотримуватися безперервності музичного процесу, причому паузи між фразами не повинні переривати вокальну лінію і поетичну думку. У цьому допоможе фортепіанна партія, яка у момент паузи в партії співака не переривається, а слугує скріплюючим елементом між окремими синтаксичними і композиційними одиницями. При всій складності німецької вимови співак повинен дотримуватися правил об' єднання приголосних з наступними складами, тим самим утворюючи безперервну вокальну лінію. У другій частині пісні, початок якої супроводжується ремаркою animato, хвилеподібне проведення вокальної лінії дає можливість співакові не зупиняти думку і рух всередині та між фразами.

У пісні «До фіалки» на високих нотах зустрічаються склади з голосною $\boldsymbol{e}$, що не дуже зручно у співі, особливо у високому регістрі. Однак в цій пісні ці звуки повинні бути насиченими і взяті за допомогою твердої атаки, але дуже м'яко, для чого необхідно легко й повітряно торкатися до них. Вдаючись до такого способу звукоутворення, співак частково нівелює незручності, пов'язані з голосною $\boldsymbol{e}$. У другій частині пісні між фразами в вокальній лінії є паузи, які співакові не слід розглядати як закінчення висловлювання. Виконавець повинен заповнити вокальні паузи інтонуванням мелодійних оборотів в фортепіанній партії за допомогою внутрішнього слуху. В середньому розділі твору тричі повторюється речення зі словом Herz на найвищих 
нотах. Його слід виконати напружено і активно, у чому вокалісту допоможе приголосна $\boldsymbol{h}$, яка в німецькій мові виконується 3 придихом. Така властивість вимови, в свою чергу, дає повне відчуття свободи, сприяючи активному підняттю м'якого піднебіння, що і потрібно вокалісту на високих нотах.

Пісня «Туга за милою» починається фразами, які одна за одною рухаються вгору. Щоб стрибки не відчувалися, а бралися одним мазком, вокалісту необхідно мислити тільки голосними, відчувати, як $\boldsymbol{i}$ плавно переходить в $\boldsymbol{e}$, а $\boldsymbol{e}$ - в наступну голосну, при цьому не забувати про чіпку вимову приголосних. Подібним чином доцільно проспівати інші фрази, щоб голосна, м'яко «перекочуючись» і протягуючись, виливалась до наступної. Такий принцип сприяє гарному та однорідному звучанню усіх голосних в одній точці, в одному сфокусованому місці. Рухливість другої частини повинна здійснюватися вокалістом не за рахунок прискорення темпу, а за допомогою більш швидкої та чіпкої вимови приголосних, не забуваючи приєднувати їх до подальших складів. У цей момент вокалісту необхідно відчувати пружину інтонування і бути психологічно максимально сконцентрованим.

З усіх пісень представленого опусу Й. Брамса четверта - «Колискова» - найбільш комфортна для співу і проста щодо мелодійного малюнку. Фортепіанна партія підтримує співака і передує його виходу за допомогою погойдуючих звуків, з яких починається вокальна лінія. На сильні долі припадають склади на сприятливі голосні $\boldsymbol{a}, \boldsymbol{o}, \boldsymbol{e}$, що обумовлює формування маслянистого переливчастого звучання голосу. В цілому, вокальна партія не становить особливих технічних труднощів; в даному випадку голос не піддається напруженості і скутості співочого апарату. Форшлаги, які зустрічаються, співакові слід проспівати якомога легше, роблячи акцент на головний звук. Складність простої на перший погляд пісні полягає в передачі голосом співака усього тепла материнської любові і щирості висловлювання. Тембр виконавця повинен бути м'яким і злегка приглушеним.

У п’ятій пісні - «Сутінки» - спостерігається безліч стрибків на широкі інтервали, для згладжування яких співакові необхідно уявляти, ніби він співає усе на одній ноті, намагатися при ході вниз нічого 
не міняти, а залишатися в тій самій високій позиції. Ще одна рекомендація - дотримуватися вокальної лінії, яка ллється, досягати безперервності звучання, чому може сприяти вслухування у фортепіанну партію, фактура якої нагадує рух струмочка. Пунктирний ритм співакові слід співати чітко, але при цьому м'яко.

Висновок. У піснях опусу 49 Й. Брамс чуйно реагує на поетичний текст. Він використовує такі принципи і прийоми музичного втілення літературного оригіналу, як, з одного боку, збереження цілісного образу, створеного автором віршів, з іншого - його деталізацію. У другому випадку композитор звертається до усіх засобів музичної виразності: мотивно-тематичного, теситурно-регістрового, ритмічного, гармонійного, фактурного. Сдиним штрихом автор акцентує окремі одиниці поетичного тексту, підхоплюючи традицію прийому ключових слів, висхідну до німецького бароко i, зокрема, творчості Й. С. Баха. Значну роль у створенні музично-поетичного образу в піснях опусу 49 грає фортепіано, партія якого спільно з вокальною забезпечує тематичну єдність кожної мініатюри. Перспективами дослідження є вивчення взаємодії словесного і музичного інтонування в інших вокальних творах Й. Брамса, а також у камерно-вокальній музиці пізніх романтиків.

\section{ЛІТЕРАТУРА}

Васина-Гроссман, В. (1966). Романтическая песня ХІХ века. Москва : Музыка, 404.

Гейрингер, К. (1965). Иоганнес Брамс. Москва : Музыка, 432.

Друскин, М. С. (1959). Иоганнес Брамс. Москва : Музыка, 142.

Михайлов, И. Д. (1987) Песенное творчество И. Брамса. (Автореф. дис. ... канд. искусствоведения). Ленинград, 22.

Попов, А. А. (1998). Словарь-справочник по практической грамматике немецкого языка «Немеикая грамматика от $A$ до Z». Москва : Лист, 272.

Царева, Е. М. (1986). Иоганнес Брамс. Москва : Музыка, 382. 


\section{REFERENCES}

Vasina-Grossman, V. (1966). Romanticheskaya pesnya XIX veka [Romantic Song of XIX century]. Moscow : Muzyka, 404.

Geyringer, K. (1965). Johannes Brahms. Moscow : Muzyka, 432.

Druskin, M. S. (1959). Johannes Brahms. Moscow : Muzyka, 142.

Mikhaylov, I. D. (1987) Pesennoe tvorchestvo I. Bramsa [by J. Brahms]. (Extended abstract of Candidate's thesis). Leningrad, 22.

Popov, A. A. (1998). Slovar-spravochnik po prakticheskoy grammatike nemetskogo yazyka "Nemetskaya grammatika ot A do Z» [DictionaryReference book of practical grammar of German language "German language from A to Z"']. Moscow : List, 272.

Tsareva, Y. M. (1986). Johannes Brahms. Moscow : Muzyka, 382.

Стаття надійшла до редакиії 10.05.2019 p. 